УДК 81 '255.2

DOI https://doi.org/10.26661/2414-1135-2021-84-10

\title{
ЛІТЕРАТУРНА КАЗКА В АСПЕКТІ ПЕРЕКЛАДУ
}

\author{
Даньшина Т. М. \\ учителька украӥнської літератури, \\ спеціалістка вищої категорії \\ Ніжсинський лічей Ніжинської міської ради \\ при Ніжинському державному університеті імені Миколи Гоголя \\ вул. Богуна 1/1, Ніжин, Чернігівська область, Україна \\ orcid.org/0000-0002-9925-4443 \\ dtmromashka@gmail.com \\ Петрик О. М. \\ кандидатка філологічних наук, \\ доцентка кафедри слов'янської філології, компаративістики та перекладу \\ Ніжинський державний університет імені Миколи Гоголя \\ вул. Графська, 2, Ніжин, Чернігівська область, Україна \\ orcid.org/0000-0002-4458-7654 \\ petrykhelena2000@gmail.com \\ Руденко А. В. \\ студентка II курсу магістратури \\ Навчально-науковий інститут філології, перекладу та журналістики \\ Ніжинського державного університету імені Миколи Гоголя \\ вул. Графська, 2, Ніжин, Чернігівська область, Украӥна \\ orcid.org/0000-0001-9836-0626 \\ rudenkoanastasia@ukr.net
}

Ключові слова: літературна казка, одомашнений переклад, відчужувальний переклад, емочійно-експресивна лексика, еквівалент, трансформація.
Наукова студія репрезентує аналіз шляхів перекладу літературної казки й визначення найоптимальніших стратегій збереження експресивного заряду тексту оригіналу. Дослідження проведено на матеріалі твору О. Волкова «Чарівник Смарагдового міста» та його перекладу українською, здійсненого Н. Косенко. У роботі вказано, що текст О. Волкова створений на основі казки американського письменника Ф. Баума «Чарівник країни Оз» 3 деякими змінами. Проте наголошено, що його варто розглядати в контексті російської традиції перекладу - адаптації (переписування, що включало додавання, розширення й доповнення зі значним ухилом щодо точності й логіки). Розкрито специфічні риси перекладу літературної казки: в основному перекладачі відмовляються від «одомашнення», але й не прагнуть «відчуження», здатного позбавити казку іiї людинодидактичної функції. Перекладач змушений дозувати співвідношення відповідників на семантичному, синтаксичному й прагматичному рівнях перекладу; він знаходиться в пошуку якоїсь універсальної стратегії, щоб зробити «чужу» вигадку своєю реальністю, щоб казка зберегла в перекладі своєрідність оригіналу. 3'ясовано особливості перекладу емоційно-експресивної лексики. Виявлено, що регулярні відповідникиеквіваленти активно функціонують у тексті казки і становлять більшу частину аналізованих одиниць. Уможливила це велика схожість у лексичному складі i граматичних структурах близькоспоріднених російської і української мов, що підтверджується спільністю походження 
і близькістю історичних шляхів розвитку. Застосування трансформацій спричинено тим, що емоційнозабарвлене слово не тільки виражає емоції мовця, а й упливає на адресата, викликаючи відповідні емоції й почуття 3 його боку. Тому в перекладі таких одиниць головне завдання - зберегти емоційно-експресивний компонент значення. Труднощі перекладу аналізованих одиниць полягають насамперед у «тонкощах семантики» й відсутності відповідних засобів вираження в мові перекладу. Транслатеми 3 емоційноекспресивним компонентом відтворюються, за умови відсутності словникового відповідника чи об'єктивної потреби контексту, в основному функціональними еквівалентами - за допомогою трансформацій-замін. Адекватна передача емоційно-експресивної лексики оригіналу - це один із шляхів вирішення проблеми перекладу літературної казки.

\title{
LITERARY FAIRY TALE IN THE ASPECT OF TRANSLATION
}

\author{
Danshina T. M. \\ Teacher of Ukrainian Language, \\ Specialist of the Highest Category \\ Nizhyn Lyceum at Nizhyn Mykola Gogol State University \\ Bogun str., 1/1, Nizhyn, Chernihiv region, Ukraine \\ orcid.org/0000-0002-9925-4443 \\ dtmromashka@gmail.com
}

Petryk O. M.

Candidate of Philological Sciences,

Associate Professor at the Department of Slavic Philology,

Comparative Studies and Translation

Mykola Gogol Nizhyn State University

Grafska str., 2, Nizhyn, Chernihiv region, Ukraine

orcid.org/0000-0002-4458-7654

petrykhelena2000@gmail.com

\author{
Rudenko A. V. \\ Master Student \\ Institute of Philology, Translation and Journalism \\ of Mykola Gogol Nizhyn State University \\ Grafska str., 2, Nizhyn, Chernihiv region, Ukraine \\ orcid.org/0000-0001-9836-0626 \\ rudenkoanastasia@ukr.net
}

Key words: literary tale, domestication, foreignization, emotionally expressive vocabulary, equivalent, transformation.
The scientific study presents an analysis of the ways of translating a literary fairy tale and determining the optimal strategies for preserving the expressive charge of the original text. The research was carried out on the basis of the text by A. Volkov "The Wizard of the Emerald City" and its translation into Ukrainian by N. Kosenko. The work indicates that the text of A. Volkov was created on the basis of the fairy tale of the American writer F. Baum "The Wonderful Wizard of Oz" with some changes. However, it was noted that it should be considered in the context of the Russian tradition of translation - adaptation (rewriting, which included extensions and additions with a significant bias towards accuracy and logic). The specific features of the translation of a literary fairy tale are revealed: basically, translators refuse to "domesticate", but they do not want "alienation" either. The translator is forced to dose the ratio of correspondences at the semantic, syntactic and pragmatic levels of translation; he is in search of a certain universal strategy to make the "foreign" 
fiction his reality, so that the fairy tale will retain the originality of the translation. The features of the translation of emotionally expressive vocabulary have been clarified. It was found that regular equivalents are actively functioning in the text of a fairy tale and make up most of the analyzed units. This has made a great similarity in the lexical composition and grammatical structures of closely related Russian and Ukrainian languages, confirmed by the common origin and the proximity of historical paths of development. The use of transformations is due to the fact that an emotionally colored word not only expresses the speaker's emotions, but also affects the addressee, evoking the corresponding emotions and feelings on his part, therefore, in translating such units, the main task is to preserve the emotionally expressive component of the meaning. First of all, difficulties in translating the analyzed units are in the "subtleties of semantics" and the lack of appropriate means of expression in the target language. A translation unit with an emotionally expressive component is translated, provided that there is no dictionary correspondence, mainly by functional equivalents - using transformations-replacements. So, an adequate transfer of the emotionally expressive vocabulary of the original is one of the ways to solve the problem of translating a literary tale.

Постановка проблеми. Одним із найцікавіших та найменш досліджених аспектів у теорії перекладу художньої літератури є проблема перекладу дитячої літератури. Це пов'язано з тим, що такі тексти набули поширення лише у XVIII столітті. Сьогодні виникає нагальна потреба в дослідженнях, присвячених перекладу літератури для дітей, позаяк вона відіграє значну роль у формуванні морально-етичного та естетико-культурного складника особистості.

Казка, у тому числі й літературна, є універсальним засобом передачі знань про довкілля i саму людину, вона покликана справляти емоційний вплив, завдяки чому краще запам'ятовується й успішніше виконує функцію трансляції знань. Тому адекватний переклад образної інформації художнього твору, а також мінімізація втрат у процесі відтворення мовної експресивності потребують прискіпливої уваги перекладознавців.

Сьогодні окремі аспекти казкового тексту розглянули: М. Дворжецька, Т. Саєнко (фонетичні), Н. Матафонова, Е. Хетч (синтаксичні), Н. Ладісова, О. Лещенко, Н. Рошияну, С. Сотнікова (стилістичні), Н. Єремеєва, Є. Мелетинський, В. Пропп, А. Греймас (структурні та семантичні), Л. Мурзін, А. Штерн, Дж. Стівенс (особливості сприйняття казки), Б. Кербеліте (діахронний розвиток), К. Мюллер, М. Мюллер, Х. Любек, Ф. Крейцар, А. Кун, Е. Тейлор, Я. Грімм, О. Афанасьєв (міфологічні витоки), О. Потебня, М. Сумцов, Г. Булашев, В. Клінгер (походження жанру), Л. Колмачевський, I. Франко, В. Гнатюк (контрастивний метод), В. Пропп, Є. Костюхін, Є. Мелетинський (історико-типологічний), Г. Сухобрус, В. Крук, I. Березовський, Л. Дунаєвська, В. Давидюк (структуру сюжетів), С. Швачко, К. Іган (можливості методичного використання). Однак проблеми перекладу літературної казки залишаються маловивченими.

Мета і завдання статті - аналіз шляхів перекладу літературної казки й визначення найоптимальніших стратегій збереження експресивного заряду тексту оригіналу.
Предмет та об'єкт дослідження. Об'єктом вивчення є літературна казка О. Волкова «Чарівник Смарагдового міста». Предмет - специфіка перекладу літературної казки та одиниць, що містять емоційно-експресивний компонент. Матеріалом слугували тексти: Волков А. Волшебник Изумрудного города. Киев: Махаон, 2010, 256 с.; Волков О. Чарівник Смарагдового міста. Переклад українською: Наталя Косенко. Харків : ВД «Школа», 2017. 224 с.; Baum Lyman Frank. The Wonderful Wizard of Oz. Kуiv : КМ-Букс, 2017. $152 \mathrm{p}$.

Виклад основного матеріалу дослідження. Казку можна вважати найпопулярнішим видом літератури для дітей. Тривала історія ії становлення й розвитку призвела до змін у цьому жанрі, нечіткості його меж. Казка може репрезентуватися у формі повісті, роману, поеми тощо. Проте, попри таке різноманіття форм, казка сприймається як окремий жанр зі своїми особливостями, які сьогодні ще не знайшли остаточного потрактування в науковому просторі.

Виокремлюючи народні, літературні й фольклорно-літературні казки [3], науковці все ж зазначають, що схожість літературної казки з народною $\epsilon$ очевидною [5].

Літературна казка, на думку Л. Брауде, - це «авторський художній прозовий або поетичний твір, заснований або на фольклорних джерелах, або придуманий самим письменником, але в будьякому разі підпорядкований його волі; твір переважно фантастичний, що змальовує чудові пригоди вигаданих або традиційних казкових героїв, і в деяких випадках орієнтований на дітей; твір, у якому чари, чудо відіграють роль сюжетотворчого чинника й допомагають схарактеризувати персонажів» [3].

Літературна казка, тяжіючи до народної моделі й відштовхуючись від неї, набуває своїх відмінних особливостей (нестійкість, нечіткість побудови; «усвідомлене авторство»; встановлений час написання й включення до тексту елементів сучасності; відсутність варіантів; головний герой - індивідуалізований; наявність індивідуального стилю 
автора; інколи має трагічний кінець, більший обсяг та продовження).

Опертя літературної казки на фольклорні традиції, прагнення авторів казок дотримуватися канонів і формул народного твору дозволяють об'єднати народну й авторську казки в один літературний жанр, а наведені відмінності не є жанродиференціювальними, вони лише демонструють різноманіття й широту жанру казки.

«Чарівник Смарагдового міста» - казкова повість О. Волкова, написана 1939 року на основі казки американського письменника Ф. Баума «Чарівник країни Оз» 3 деякими змінами. Популярність «Чарівника Смарагдового міста» підтверджена багатьма екранізаціями, театральними постановками й продовженнями історії (серія «Смарагдове місто», «Казки Смарагдового міста» С. Сухінова, «Смарагдовий дощ» Ю. Кузнецова).

Хоча сама книга О. Волкова написана на основі твору Ф. Баума, проте вона була також перекладена багатьма мовами, у тому числі англійською та німецькою, і видана майже в усіх колишніх соціалістичних країнах. Українською текст перекладали Ф. Ксензенко (1992) та Н. Косенко (2013). Видавництво «Веселка» видавало повість 3 перекладом М. Зяблюка.

Американська дослідниця Еріка Хабер 2017 року звернулася до аналізу зазначеного твору, опублікувавши монографічне дослідження "Behind the Iron Curtain. Aleksandr Volkov and His "Magic Land” Series» («За залізною завісою. Олександр Волков і його серія “Чарівна земля”»).

Авторка розвідки зазначає, що ці дві чарівних історії - книга американського письменника Ф. Баума про Країну Оз і казкові повісті О. Волкова про Чарівну країну - не просто улюблені дитячі книжки багатьох поколінь читачів, а й найпопулярніші меми XX ст. [6]. Причому в США і в Росії ці книги, створені в різних умовах і з різними завданнями, сприймаються як зразки саме національних чарівних казок - американської та радянської, і вважаються знаковими культурними явищами. Попри це, ні самі книги, ні їхні автори не викликали інтересу в дослідників і критиків [6, c. 125$]$.

Одне 3 основних питань, яке неминуче постає перед тими, хто намагається порівнювати книги про Країну Оз з російськими казковими повістями про Чарівну країну, - чи слід вважати «Чарівника Смарагдового міста» О. Волкова перекладом або переказом «Чарівника Країни Оз» Ф. Баума.

Книгу О. Волкова варто розглядати саме в контексті російської традиції перекладу: адаптації були вельми поширені в російській видавничій практиці («Айболить» К. Чуковського, «Буратіно» О. Толстого). «У ранній радянській культурі запозичення контенту й радикальна переробка його форми, тобто переписування оригінального тексту, вважалося цілком прийнятним і навіть кращим, оскільки дозволяло увідповіднювати текст 3 радянською ідеологією і вимогами цензури» [6, с. 146]. Відзначаючи високі художні достоїнства «Чарівника Смарагдового міста», Еріка Хабер називає книгу «переробленою й покращеною версією книги Баума» [6, с. 3], причому наголошує, що «замість перекладу або адаптації зусилля Волкова були спрямовані на переписування, що включало додавання, розширення й доповнення зі значним ухилом щодо точності й логіки. Це була не ідеологічна ревізія, а педагогічна, націлена на створення кращого виховного впливу на читача-дитину» [6, с. 148]. Проте аналізований український варіант казки «Чарівник Смарагдового міста» $є$ яскравим прикладом перекладу.

Для передачі національної специфіки оригінального тексту й збереження при цьому цілісності художнього впливу на реципієнта мовою перекладу одних лінгвістичних знань замало. На думку Т. Казакової, фольклор, зокрема казка, це специфічний об'єкт, що становить великі труднощі для перекладу [4, с. 74-75]. Казковий дуалізм (універсальне / специфічне, вимисел / реальність, людичність / дидактичність) надає цьому жанру особливого статусу в процесі перекладу перенесення на новий культурний, літературний, етнічний грунт, в інше мовне середовище.

Серед сучасних стратегій перекладу, що корелюють із двома основними підходами до перекладу казок (науковий переклад, що прагне до точності в передачі сенсу й форми оригіналу (адресується фахівцям); і літературно-художній переклад, який допускає відступи в деталях за збереження основної сюжетної лінії, забезпечуючи розважально-пізнавальну та виховну функції (враховує інтереси ширшої, в основному дитячої аудиторії) [2, с. 273]), чітко виділяються відчужувальний переклад (аналітичний / форенізація) та одомашнений (синтетичний / доместикація) [7]. У перекладі народної казки стратегія «одомашнення», тобто «адаптації» перекладного матеріалу і його пристосування до лінгвістичних, національних, соціальних реалій перекладної культури, переважає. Проте в перекладі літературної казки в основному перекладачі відмовляються від «одомашнення», але й не прагнуть до іншої крайності - «відчуження», здатної позбавити казку іiі людино-дидактичної функції в силу зайвої складності й невпізнання. Перекладач змушений дозувати співвідношення відповідників на семантичному, синтаксичному й прагматичному рівнях перекладу; він знаходиться в пошуку якоїсь універсальної стратегії, щоб зробити «чужу» вигадку своєю реальністю, щоб казка, знаходячи природне звучання чужою мовою, зберегла в перекладі своєрідність оригіналу. 
У процесі перекладу казок слід звертати особливу увагу на стійкі формули, промовисті імена, римовані рядки, недоторкані символи, закони казкової логіки. Адекватності сприйняття носіями мови перекладу можна досягти за допомогою таких прийомів: а) транскрипиіï і транслітераuiï, що часто застосовується з метою збереження національно-культурної специфіки, проте в казкових текстах такий прийом використовується нечасто, за надмірного його використання можуть виникнути проблеми, оскільки велика кількість транскрибованих слів без коментаря може утруднити розуміння тексту (аршин / аршин, копа /копа, боярин / боярин, кокошник / кокошник); б) калькування, унаслідок чого зберігається загальна семантика слова (локоть / лікоть, Золушка / Попелюшка, серебряное блюдечко с золотой каёмочкой / срібне блюдечко із золотою облямівочкою); в) наближений переклад (або різні види замін) (теремок / дімок); г) адекватний аналог (красна девица / панна). Також часто використовуваними є лексичні додавання, описовий переклад, модулячія та компенсачія.

Крім того, працюючи над перекладом, перекладач повинен пам'ятати, що категорія експресивності $€$ основною властивістю мови казки. Емоційно-експресивна лексика виступає ефективним засобом активного впливу на читача-дитину, тому потрібно намагатися зберегти функцію експресивного слова в перекладному тексті. Важливо враховувати, що кожна мова має характерний саме для неї набір експресивно-стилістичних засобів. У російській та українській мовах, наприклад, відзначається загальна тенденція до опори як на семантичні елементи, так і на словотвірні. В англійській мові переважно використовуються формальні елементи.

Отже, перекладачеві під час сприйняття й усвідомлення тексту оригіналу варто послуговуватися компонентним аналізом для з'ясування тих засобів, за допомогою яких відтворюється емоційно-експресивне значення тієї чи іншої лексеми. Крім того, варто уникати копіювання експресивних засобів оригіналу, оскільки в мові перекладу вони можуть бути відсутніми або виконувати іншу функціональну роль у семантиці слова й тексту загалом.

Провівши зіставлення й аналіз текстів оригіналу «Волшебник Изумрудного города» та перекладу «Чарівник Смарагдового міста», можемо зробити висновок, що відтворення емоційно-експресивної лексики відбувається у два основних способи: 1) використання регулярних відповідників (еквівалентів), 2) застосування трансформацій.

Використання регулярних відповідників (еквівалентів)

Повними еквівалентами вважаємо такі одиниці, які під час перекладу зберігають не тільки предметно-логічне значення, а й конотативно-прагматичний компонент у семантичній структурі емоційно-експресивної одиниці, напр.: Только чёрненький зверек смело вступился за неё и укусил Людоеда, но тот так хватил его своей огромной ногой, что он, наверное, умрет.../ Тільки чорненьке звірятко хоробро заступилося за неї і вкусило Людожкера, але той так зацідив йому своєю величезною ногою, що він, напевно, nомре.

Трапляються випадки, коли відповідники-еквіваленти в тексті друготвору, зважаючи на мовні норми перекладної мови, функціонують в іншій граматичній формі, напр.: Фермер Джон поехал в соседний городок на ярмарку и повел девочку в иирк / Фермер Джон пойхав до сусіднього містечка на ярмарок і повів дівчинку в циик (мужской род, винительный падеж / середній рід, родовий відмінок).

Цікавим з боку адекватності є такий приклад:Неужели хилая девчонка осилила могущественную Гингему, повелительнииу Жевунов? / - Невже така слабенька дівчинка подужала могутню Гінгему, повелительку Жувунів? Це той випадок, коли еквівалентний переклад не є адекватним. В оригіналі автор за допомогою слів хилая (слабый, болезненный, немощныій) та девчонка (разговорное, уничижительное), які уклав в уста чаклунки Бастінди, дає ій негативну характеристику, розкриває злу вдачу, підкреслюючи іiі ненависне ставлення до людей. У перекладі лексеми слабенька (зменшено-пестливе до слабий) та дівчинка (зі зменшено-пестливим суфіксом), що є відповідниками, не виконують тієї функції, що в оригіналі: вони $€$ характеристичними, проте конотація в них протилежна - позитивна, ці слова не допомагають розкрити злісний характер чаклунки, а відтак не можуть справити відповідного впливу на читача.

Умовно частковими еквівалентами вважаємо такі транслатеми, які під час перекладу повністю зберігають предметно-логічне значення, проте абсолютно втрачають конотативно-прагматичний компонент у семантичній структурі емоційно-експресивної одиниці, напр.: Он рычал от злости, и его сапожищи грохотали: "Ton-mon-mon...» / Він розлючено ревів, гуркочучи чобітьми: тупmyn-myn!...(втрачений засіб - суфікс, що надає відтінку збільшеності та згрубілості).

Отже, регулярні відповідники-еквіваленти активно функціонують у тексті казки і становлять більшу частину аналізованих одиниць. Уможливила це велика схожість у лексичному складі i граматичних структурах близькоспоріднених російської і української мов, що підтверджується спільністю походження і близькістю історичних шляхів розвитку російського і українського народів - носіїв цих мов. 
Застосування трансформацій

У перекладі підбір функціональних відповідників визначається в таких випадках, коли за мовних умов немає можливості відтворити одночасно, з одного боку, речовинний зміст тексту-оригіналу і смислову функцію граматичної форми (або лексико-стилістичну особливість оригіналу), 3 іншого. Саме 3 цієї причини в таких ситуаціях ставиться завдання про вибір певних трансформацій [1, с. 158] (міжмовних перетворень, що вимагають перебудови на лексичному, граматичному чи лексико-граматичному рівнях) для передачі тексту оригіналу.

Заміна лексемою, у семантичній структурі якої зберігається емоційно-експресивний компонент значення, напр.: - $O$, с удовольствием, $c$ великим удовольствием! - дружно заревело звериное сборище / $-O$, із задоволенням, з великою padicmю! - одностайно заревло звірине зборище. В оригіналі лексема удовольствие (чувство радости, довольства от приятных ощущений, переживаний) відтворена словом радість (почуття задоволення, втіха, приємність), яке виступає гіперонімом щодо оригіналу. У цьому разі представлено окремий вид лексичних замін - генералізацію.

Заміна лексемою, у семантичній структурі якої посилюеться емоційно-експресивний компонент, напр.: - Я буду держать тебя в рабстве и, если будешь плохо работать, побью тебя большой палкой и посажу в темный подвал, где крысы - огромные жадные крысы! - съедят тебя и обгложут твои нежные косточки! / - Я триматиму тебе в рабстві та, якщзо погано праијюватимеш, добряче відрепаю палицею $і$ вкину до темного льоху, де щури - величезні голоднючі щури! - зжеруть тебе й обсмокчуть твої ніжні кісточки! У перекладі за допомогою лексем, що містять функціонально-стилістичні обмеження у вживанні (розмовне мовлення (відрепаю - авторський новотвір, зжеруть - ремарка вульгарне)), не лише досягається максимальна експресивність висловлення, а й відбувається характеристика образу через його мовлення.

Заміна лексемою, у семантичній структурі якої послаблюсться емоційно-експресивний компонент, напр.: Он [Рольф] делал детям чудесные ветряные мельницы / Він майстрував для дітей гарні вітряки. В оригіналі акцент зроблено не стільки на красі та зовнішньому вигляді іграшки (гарний - приємний зовнішнім виглядом; який відзначається гармонією барв, ліній тощо), скільки на незвичності, дивовижності іiї (чудесныцй -удивительный, необычныци).

Замінами-додаваннями вважаємо такі перекладацькі трансформації, унаслідок яких слово мови оригіналу, що належить до нейтральної лек- сики, замінюється одиницею мови перекладу, що не $є$ його прямим словниковим відповідником, причому в семантиці одиниці мови перекладу 3'являється емоційно-експресивний компонент, напр.: Последние годы Людоед прятался в лесу, ловил неосторожного кролика или зайца и съедал его с кожей и костями / Останні роки Людожер ховався в лісі, ловив якогось необережного кроля або зайия, уминаючи ӥх иілком, зі шкурою та кістками. У російській мові лексема съедать (поглощать пищу, питаться, насыщаться) позбавлена експресивності, тоді як в українській мові іiі заміна уминати (розм. їсти швидко, із смаком, жадібно, багато) відзначається наявністю 1) емоційного компонента - негативна емоційна оцінка за рахунок семи 'жадібно', 2) оцінного компонента - негативна оцінка, 3) експресивного компонента (підсиленої виразності) - швидко й багато, 4) стилістичного компонента - розмовний.

Заміни-опущення кваліфікуємо як перекладацькі заміни, унаслідок яких в одиниці мови перекладу, що не $є$ словниковим відповідником, втрачається емоційно-експресивний компонент i вона переходить до розряду нейтральної лексики, напр.: Это была самая восхитительная и уютная комната в мире, с маленькой кроватью, $c$ фонтаном посредине, из которого била тоненькая струйка воды, падавшая в красивый бассейн / Це була найчудовіша та найзатишніша кімнатка у світі, з маленьким ліжечком, із фонтаном посередині, з якого струменіла вода, спадаючи в красивий басейн. Перекладач не зберіг експресивного компонента - інтенсивності дії бить ( с силой вырывваться откуда-л., вытекать стремительной струёй (о жидкости, паре и т.n.) / струменіти (литися, текти струменем, вузенькою цівкою).

Опущеннями вважаємо окремий вид трансформацій, під час яких через об'єктивні чи суб'єктивні чинники перекладач опускає транслатему з емоційно-експресивним забарвленням; ні формальний, ні змістовий ії бік не відтворено в друготворі. Найчастіше такі трансформації застосовуються під час надмірного нанизування інформації в оригіналі для спрощення розуміння тексту казки. Проте втрата експресивно забарвленої одиниці позбавляс висловлення прагматичної функції, що призводить до порушення адекватності в перекладі казки. Порівн.: $B$ эту ночь Элли спала в дупле, на мягкой постельке из мха и листьев / Цієї ночі Еллі спала в дуплі, м'яко вистеленому мохом $i$ листям. Висловлення друготвору позбавлене характеристичної функції: якщо в оригіналі наявна авторська оцінка героя (засіб - зменшено-пестливий суфікс), то в перекладі її немає.

Додавання - це протилежний щодо опущення вид трансформації, унаслідок якої через об'єктивні чи суб'єктивні чинники перекладач 
додає мовну одиницю $з$ емоційно-експресивним забарвленням у друготворі. Найчастіше це відбувається 3 певною стилістичною метою, для кращого розкриття підтексту, характеристики образу чи відновлення ритмічної структури казки, напр.: Плохо мое дело: ведь я пальцем не могу тронуть маленькую нахалку, пока на ней волшебные башмачки / Еге, кепські мої справи: я ж тепер $i$ пальцем не зможу зачепити маленьку нахабу, поки на ній чарівні черевички. Додана стверджувальна частка акцентує увагу на висловленому, привертає увагу читача, разом з тим імпліцитно представляє ставлення автора / інтерпретатора до героя твору.

Застосування трансформацій спричинено тим, що емоційно-забарвлене слово не тільки виражає емоції мовця, а й упливає на адресата, викликаючи відповідні емоції й почуття 3 його боку. $\mathrm{y}$ перекладі таких одиниць головне завдання зберегти емоційно-експресивний компонент значення. Труднощі перекладу аналізованої лексики полягають передусім у «тонкощах семантики» й відсутності відповідних засобів вираження в мові перекладу. Тому транслатеми 3 емоційно-експресивним компонентом відтворюються, за умови відсутності словникового відповідника чи об'єктивної потреби контексту, за допомогою різних видів трансформацій.

Висновки і перспективи подальших розробок. Казка являє собою багатовимірний феномен людської культури, як 3 точки зору просторово-часового й композиційно-сюжетного побутування, так і в плані можливостей інтерпретації, різноманітності її функцій та варіативності адресатів. Проведені культурологічний, лінгвостилістичний та перекладацький аналізи першотвору й друготвору виявили, що адекватне відтворення емоційно-експресивної лексики в перекладі тексту художньої дитячої літератури один з основних шляхів до вирішення проблеми перекладу казки. Подальше дослідження означеної теми вважаємо перспективним, позаяк воно спрямоване на 3'ясування й уточнення перекладацьких стратегій щодо специфіки відтворення лексики $з$ емоційно-експресивним компонентом і уточнює розуміння естетичної та прагматичної функції перекладу літератури для дітей.

\section{ЛIТЕРАТУРА}

1. Алексеева И.С. Введение в переводоведение : учеб. пособие для студ. филол. и лингв. фак. высш. учеб. заведений. Санкт-Петербург : Филологический факультет СПбГУ ; Москва : Издательский центр «Академия», 2004. 352 с.
2. Богрданова Т.Н. Русская сказка в англоязычной традиции перевода. Вестник ТГУ. 2010. № 4 (84). C. 268-274.

3. Брауде Л.Ю. Скандинавская литературная сказка. Москва : Наука, 1979. 208 с.

4. Казакова Т.А. Практические основы перевода. English-Russian : учебное пособие. Санкт-Петербург : «Издательство Союз», 2001. 320 с.

5. Цикушева И.В. Жанровые особенности литературной сказки (на материале русской и английской литературы). Вестник Адыгейского государственного университета. Сер. 2. Филология и искусствоведение. 2008. № 1. C. 52-55.

6. Haber Erika. Behind the Iron Curtain. Aleksandr Volkov and His "Magic Land" Series. Jackson : University Press of Mississippi, 2017. 297 p.

7. Schleiermacher F. Über die verschiedenen Methoden des. Friedrich Schleiermachers sämmtliche Werke. Dritte Abteilung. Zur Philosopie. Zweiter Band. Berlin, 1838. P. 207-245.

\section{REFERENCES}

1. Alekseeva, I.S. (2004). Vvedenie $v$ perevodovedenie [Introduction to Translation Studies]. Sankt-Peterburg : Filologicheskiy fakul'tet SPbGU; Moskva : Izdatel'skiy tsentr «Akademiya» [in Russian].

2. Bogrdanova, T.N. (2010). Russkaya skazka v angloyazychnoy traditsii perevoda [Russian fairy tale in the English tradition of translation]. Vestnik TGU - Tomsk State University Journal, 4 (84), 268-274 [in Russian].

3. Braude, L.Yu. (1979). Skandinavskaya literaturnaya skazka [Scandinavian literary tale]. Moskva : Nauka [in Russian].

4. Kazakova, T.A. (2001). Prakticheskie osnovy perevoda. English - Russian [Practical translation basics. English - Russian]. Sankt-Peterburg : "Izdatel'stvo Soyuz" [in Russian].

5. Tsikusheva, I.V. (2008). Zhanrovye osobennosti literaturnoy skazki (na materiale russkoy i angliyskoy literatury) [Genre features of a literary tale]. Vestnik Adygeyskogo gosudarstvennogo universiteta - Adyghe State University Journal, Vol. 2, 1, 52-55 [in Russian].

6. Haber Erika. Behind the Iron Curtain. Aleksandr Volkov and His "Magic Land" Series. Jackson: University Press of Mississippi, 2017. 297 p.

7. Schleiermacher F. Über die verschiedenen Methoden des. Friedrich Schleiermachers sämmtliche Werke. Dritte Abteilung. Zur Philosopie. Zweiter Band. Berlin, 1838. P. 207-245. 